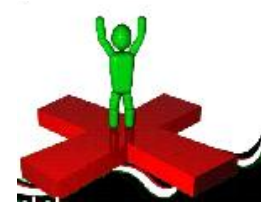

\title{
A study on nutritional assessment of jaundice patient and its prevalence in urban areas of Faizabad district
}

\section{VANDANA GUPTA AND VIRGINIA PAUL}

See end of the paper for authors' affiliation Correspondence to : VANDANA GUPTA Department of Food and Nutrition, Ethelind School of Home Science, Sam Higginbottom Institute of Agriculture, Technology and Sciences, ALLAHABAD (U.P.) INDIA

Email: vandu.v.23@

gmail.com

\section{KEY WORDS :}

Prevalence, Jaundice, Serum bilirubin level
ABSTRACT : Jaundice is a common problem in medical and surgical gastroenterological practice. Its cause can often be correctly anticipated clinically but usually investigations are required for confirmation. It could be because of a variety of causes and is less commonly seen outside the gastroenterology and hepatobiliary surgery. Information on the prevalence of jaundice in the inhabitants of four hospitals namely Chiranjeev, Chinmay, Vaishnavi and Janki was very scanty. For the collection of information, 400 patients were assessed in which 60 patients were selected randomly in which 66.67 per cent were male and 33.33 per cent were female. The main objectives of the study were to find out the prevalence, their nutritional status and dietary pattern. In present study, the serum bilirubin level was assessed for the confirmation of the jaundice in patients. The different types of test relevant to jaundice were also assessed. The findings of the study showed that out of 60 patients $(100 \%), 58(98 \%)$ patients had the serum bilirubin level in the range of 1.0 to 5.0 $\mathrm{mg} / \mathrm{dl}$ which showed mild symptoms and $2(2 \%)$ patients had the serum bilirubin level in the range of more than $10.0 \mathrm{mg} / \mathrm{dl}$ which showed severe symptoms in the patients.

How to cite this paper : Gupta, Vandana and Paul, Virginia (2015). A study on nutritional assessment of jaundice patient and its prevalence in urban areas of Faizabad district. Internat. J. Med. Sci., 8(1\&2) : 2024. 